\title{
SOCIO-ECONOMIC DETERMINANTS OF FARMERS' PARTICIPATION IN OFF-FARM INCOME EMPLOYMENT IN EZZA SOUTH LOCAL GOVERNMENT AREA OF EBONYI STATE, NIGERIA.
}

\section{DETERMINANTES SOCIOECONÓMICOS DE LA PARTICIPACIÓN DE LOS AGRICULTORES EN EL EMPLEO DE INGRESOS NO AGRÍCOLAS EN EL ÁREA DEL GOBIERNO LOCAL DE EZZA SOUTH DEL ESTADO DE EBONYI, NIGERIA.}

\author{
Samuel Obinna Ucha ${ }^{1}$, Smiles Ifeanyichukwu Ume ${ }^{1}$, and Justin, Nnaji ${ }^{2}$ \\ ${ }^{1}$ Department of Agricultural Extension and Management. Federal College of Agriculture \\ Ishiagu, Ivo Local Government Area of Ebonyi State, Nigeria. \\ 2Department of Cooperative Economics and Management. Federal College of Agriculture \\ Ishiagu, Ivo Local Government Area of Ebonyi State, Nigeria. \\ Corresponding Author, E-mail: umesmilesi@gmail.com
}

\section{ABSTRACT}

The socio-economic determinants of farmers' participation in off-farm income employment in Ezza south local government area of Ebonyi state, Nigeria was studied. The specific objectives of the study were to describe the socio-economic characteristics of the farmers, identify the off-farm income employments participated by the farmers, ascertain the determinants of farmers' participation in off-farm income employments and identify the limiting factors to the farmers' participation in off-farm income employments in the study area. A multistage random sampling procedure was used to select respondents for the study. One hundred and twenty (120) farmers were randomly selected for the study. Data collected were analyzed using percentage responses and frequency distribution, logistic regression and 4-point Likert scale. The findings revealed that the farmers that participated in off-farm income activities were aged, educated, well experienced, large farm size, females, married and large household size. The result further revealed that high proportion of the respondents engaged in civil service, trading, motor cycle riders, auto mechanics and tricycle riders. The determinants factors to the farmers' participants in off farm employments were household size, education level, farming experience, farm size and membership of cooperative societies. Factors limiting 
farmers' participation in off-farm activities were high level of illiteracy, poor access to credit facility, old age, inadequate power supply, poor extension services and ill health of farmers identified. There is need to enhance farmers' access to extension services, educational program, encouraged farmers to join or form cooperatives.

Key-words: Socio-economic, Determinants, Farmers, Participation, Off- farm, Income, Activities

\section{RESUMEN}

Se estudiaron los determinantes socioeconómicos de la participación de los agricultores en el empleo de ingresos no agrícolas en el área del gobierno local del sur de Ezza en el estado de Ebonyi, Nigeria. Los objetivos específicos del estudio fueron describir las características socioeconómicas de los agricultores, identificar los empleos de ingresos no agrícolas participados por los agricultores, determinar los determinantes de la participación de los agricultores en empleos de ingresos no agrícolas e identificar los factores limitantes para participación de los agricultores en empleos de ingresos no agrícolas en el área de estudio. Se usó un procedimiento de muestreo aleatorio de etapas múltiples para seleccionar a los encuestados para el estudio. Ciento veinte agricultores (120) fueron seleccionados al azar para el estudio. Los datos recopilados se analizaron utilizando respuestas porcentuales y distribución de frecuencias, regresión logística y escala Likert de 4 puntos. Los resultados revelaron que los agricultores que participaron en actividades de ingresos fuera de la granja eran ancianos, educados, con experiencia, gran tamaño de granja, mujeres, casadas y gran tamaño de hogar. El resultado reveló además que una alta proporción de los encuestados se dedicaba al servicio civil, comercio, motociclistas, mecánicos de automóviles y ciclistas. Los factores determinantes para los participantes de los agricultores en empleos fuera de la granja fueron el tamaño del hogar, el nivel de educación, la experiencia agrícola, el tamaño de la granja y la membresía de sociedades cooperativas. Los factores que limitan la participación de los agricultores en las actividades fuera de la granja fueron el alto nivel de analfabetismo, el acceso deficiente al crédito, la vejez, el suministro de energía inadecuado, los servicios de extensión deficientes y la mala salud de los agricultores identificados. Es necesario mejorar el acceso de los agricultores a los servicios de extensión, el programa educativo, alentar a los agricultores a unirse o formar cooperativas.

Palabras clave: Socioeconómico, Determinantes Agricultores, Participación, Fuera de la granja, Ingresos, Actividades 


\section{INTRODUCTION}

Off- farm income activities have received interest from researchers and policy-makers in the past decades, with soaring optimism that advancing it can proffer an alleyway in enhancing farmers' access to credit and agricultural development in countries especially in subSaharan Africa (SSA) (Haggleladeet al. 2003, Lagerkvist al. 2006). Nonfarm income generating activities as opined by Ume et al. (2018) are those incomes received by the farmer from nonfarm income activities at different times of the year. The participation in nonfarm activities is the farmers' approach for broaden their horizons of household earnings portfolio (Ellis and Freeman 2004). The basics of engaging in nonfarm income generating activities by farmers according to studies are to secure better living standards by reducing risk, reduce income inequality among rural households vulnerability and lessening the harshness of poverty, maintain their household income and soothe their household expenditure over a lengthened time, enhancing security and increasing assets (Yue and Sonado2012)

Globally, the figure of farmers engaged in off farm income activities as reported by Reardon et al. (1998) is about 58\%, with some countries having contribution as high as $75 \%$ of total income on average. The case of developing countries may not be very palatable as offfarm income activities as asserted by Haggbladeet al. (2010) is responsible for between $35 \%$ and $50 \%$ of total income of rural households. Literatures show that "pull and "push factors" have been responsible for participation of farmers in off - farm income activities. The pulled factors include higher returns to labour and or capital and high-risk and low-potential agricultural environments subject to drought, flooding and environmental degradation (Beyene 2008, 2009). While, the push factors are land constraints, climate change, market access problems due to poor infrastructure and high transaction cost (Reardon, 1997; Barrett et al., 2001, Minot et al., 2006). The off-farm income generating or rural non-farm activities vary across geo-political locations and countries. The major off-farm income generating activities which the farmers engaged in most countries in sub-Saharan Africa, includedfood processing, trading, mat weaving and pottery (Kowonet al. 2006, Biornsen and Misha 2012). Others are weaving, smithery, tannery, basketry, mat-making, carving, brass casting, wine tapping, hair dressing, petty trading, medical practice, driving, money lending, bicycle and shoe repairing (Biornsen and Misha 2012).

Generally, studies found that some of these nonfarm income generating activities are carried out concurrently during farming season, while others are carried out only during offseason periods. For example, Ruben and Vand -Berg (2001) reported that off farm activities that may possibly carried out at the same time with farming activities, included game animals, dancing and singing, local pomade preparation, night guard, fruit gathering, casual labour, rubber tapping, palm wine tapping and processing, fuel wood vendor, and casual labour. The nonfarm income generating activities according to Reardon (1998) and Rahman, (2007) that may perhaps be carried out during off-season, including brick layer, cement block moulding, 
transportation business, fish traps/baskets weaving, local gin distillation, carpentry and sculptural designs.

Studies on socio- economic determinant factors affecting farmers' participation in these off-farm income employment in Africa are many (Mishra and Sandretto2001, Arearn, El-osta and Dwebre2006, Misha and Holthausen 2002; Ncnamara and Weiss 2005) and similarly, in some part of Nigeria (Babatunde, et al. 2010, Ovwigho 2014, Ume et al. 2018). The factors often cited by scholars that are based on individual, family and farm characteristics (Ellis and Freeman 2004; Biornsen and Misha 2012), including age of the farmer, educational level, gender, membership of organization farming experience, farm ownership, government payments farm size and farm type (Ellis and Freeman2004, Kwon et al.,2006; Lagerkvist et al. 2006).However, to the best knowledge of the researcher, no published work on the subject matter in the study area, hence the need for this study becomes imperative as that may perhaps append to intellectual development as it will serve as a guide to scientist for further research and to enhance farmers' participation in off-farm income in order improve their livelihood.

Specifically, the objectives were to: 1 ) describe the socio-economic characteristics of the farmers, 2) identify the off-farm income employments participated by the farmers, 3) assess the socio economic determinants farmers participation in off-farm income activities, 4) identify the limiting factors to farmers' participation in off-farm income in the study area.

\section{MATERIALS AND METHODS}

Ezza South Local Government Area is one of the Local Government Areas in Ebonyi State of Nigeria. It is geographically located between Latitude $60^{\circ} .8^{\prime} \mathrm{N}$ and $60^{\circ} .13^{\prime} \mathrm{N}$ of the Equator and Longitude $80^{\circ} \mathrm{E}$ and $80^{\circ} .5^{\prime} \mathrm{E}$ of Greenwich Meridian. The Local Government Area has a population of about 133,625 people (National Population Commission, (NPC), 2006) and a land area of $324 \mathrm{Km}^{2}$. The area is bounded in the north by Abakaliki Local Government Area in the south by Afikpo North and Onicha Local Government Areas. In the east, by Ikwo Local Government Area and in the west, by Ezza North Local Government Area. The area has two seasons; rainy season (March - October) and dry season (November - February). It has a mean temperature of $21^{\circ} \mathrm{C}$ during cold period and the mean annual rainfall is approximately $1200 \mathrm{~mm}$. The major crops grown in the area are yam, cassava, rice, cocoyam, and sweet potatoes. Other cash crops produced in the study area are Oil palm, coconut, orange, pears, mango and bush mango. People rear livestock like goat, poultry, sheep and local cattle. The nonagricultural practices by the farmers are hunting, trading, saloon, tailoring, auto mechanics and vulcanizer. 
A multi-stage random sampling procedure was used to select communities and respondents for the study. In the first stage, six (6) communities were randomly selected from the ten (10) communities that made up the local government area. In the second stage, Two (2) villages were randomly selected from each of six communities selected. Finally, Ten (10) farmers were be randomly selected from each the twelve (12) villages. This brought to total of one hundred and twenty (120) farmers for detailed study. A well-structured questionnaire and oral interview were used to collect data required for the study. The objectives i and ii were captured using percentages responses and frequency distribution Table. Objective iii and iv were realized using binomial logistic and 4 point Likert scale respectively.

Model Specification - Logistic Regression Model: The Logistic regression model gives the effect of the various factors affecting farmers' participation in off farm employment. The dependentvariable in the empirical model is whether or not the farmer participated in the off arm activitiesor not and the logistic regression characterizing the participation of farmers in off farm income generating activities by the sample farmers is specified as follows:

$$
E(Y i)=P(Y i)=e a+\beta X i / 1+e a+\beta X i(1)
$$

$\mathrm{Pi}$ is the probability of the ith farmer with ith attributes likely to participate in off farm activities

$\mathrm{E}(\mathrm{Yi})+\mathrm{P}(\mathrm{Yi})=1$, where $\mathrm{Yi}=1$ if the individual farmer participated and $\mathrm{Yi}=0$ if the Individual farmer does not participate.

$\mathrm{Xi}$ represents a vector of features linked to the ith individual. $\beta i$ isthe vector of the estimated coefficients. The regression model is linearlized as follows;

$$
\text { In }(\mathrm{pi} / \mathrm{(1-} \mathrm{pi})=\beta \mathrm{o}+\beta_{1} \mathrm{X}_{1}+\beta_{2} \mathrm{X}_{2} \ldots \beta_{8} \mathrm{X}_{8}+\varepsilon \text { (2) }
$$

The dependent variable is the natural log of the odd of participating $(P)$ divided by the odds of not participating (1-P). $\beta 0$ is the intercept term, and $\beta_{1}, \beta_{2} \ldots \ldots \beta_{8}$ are the coefficients associated with each explanatory variable, $\mathrm{X}_{1}, \mathrm{X}_{2} \ldots \ldots . . . \mathrm{X}_{8}$. The formation of the logistic model was based on the hypothesis that a farmer's decision to Participate or not at any time is subjective by the collective effect (simultaneous) outcome of hypothesized socio-economic factors. The variables that were employed in the logistic model were predicted using the maximum likelihood method.

Explicitly logistic regression model can be symbolized as

$$
\begin{aligned}
& Y=b_{0}+b_{1} X_{1}+b_{2} X_{2}+b_{3} X_{3}+b_{4} X_{4}+b_{5} X_{5}+b_{6} X_{6}+b_{7} X_{7}+b_{8} X_{8}+e(3) \\
& Y=\text { participation in off-farm activities (dummy; yes }=1 \text {, No }=0 \text { ) } \\
& \left.X_{1}=\text { Gender (dummy variable: Male }=1, \text { Female }=0\right) \\
& X_{2}=\text { Age of respondent (years) } \\
& \left.X_{3}=\text { Marital status (1 if married, otherwise } 0\right) \\
& X_{4}=\text { Household Size (number) } \\
& X_{5}=\text { Educational qualification (years) }
\end{aligned}
$$


Sustainability, Agri, Food and Environmental Research, (ISSN: 0719-3726), 8(2): 155-170 http://dx.doi.org/10.7770/safer-VONO-art1957

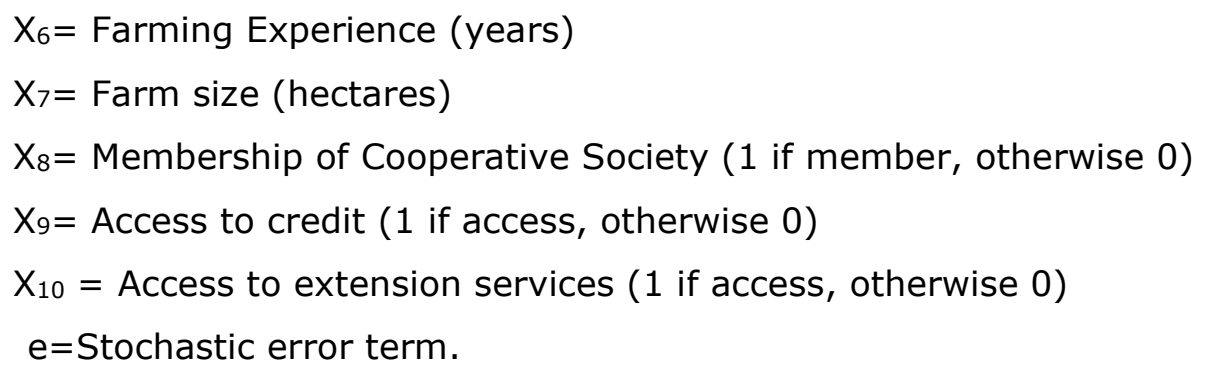

Four Point Likert Scale: The constraints to farmers' participation in off farm income by the respondent was measured using the 4 point Likert scale not serious (0), serious (1), fairly serious(2), very serious (3). To determine the mean of seriousness $x=£ x$ the mean core $x$, of each item was computed by multiplying the frequency of each response patterning to its appropriate normal value and dividing the sum with the number of respondents to the items. This can be summarized with the equation become

$$
\begin{gathered}
\text { where } \mathrm{X}=\text { mean score } \\
\Sigma=\text { summation } \\
\mathrm{N}=\text { frequency } \\
\mathrm{n}=\text { Likert norminal value } \\
\overline{\mathrm{X}}=\frac{0+1+2+3=6=1.5}{4}
\end{gathered}
$$$$
X=\Sigma \mathrm{fn} / \mathrm{n}
$$

Analysis of the constraint was done by means of a critical mean of 1.5 .

\section{RESULTS AND DISCUSSION}

The high proportions of females above males may possibly be linked to their entrepreneurial abilities and economic roles in household welfare improvement (Babatunde et al., 2010). More so, majority of the respondents (68.3\%) were married followed by the widow $(17.5 \%)$ whereas single farmers were the least (14.2\%). The married people are expected to have dependents, who can be deployed to off farm income activities especially during off season, in order to supplement the household meager resources for family up keeping(Mishra and Sandretto 2001). As well, majority of the farmers $(32.5 \%)$ had household size of 7-10 persons, followed by those with the household size of 4-6 persons (31.7\%). The least were those with 1-3 persons (13.3\%). This implies that the farmers had large household size, which leads to many responsibilities of which the farmers should engage in off-farm income to solve the problems. This finding was in line with Zahonogo (2011) who stated that household size was among the determinant factors in participating in off- farm activities. Furthermore, majority $(30 \%)$ of the respondents spent 7- 12 years in school, whereas the least $(18.3 \%)$ had no formal education. Education is likely to boost entrepreneurial abilities and self-employment, 
which might increase their inclination to engage in higher-return nonfarm activities. Furthermore, lack of education bring into being entry obstacle to definite off-farm employment prospects, hence leading to labour market dualism (Ellis and Freeman 2004). This is in agreement with the findings of Haggbladeet al. (2010). Moreover, 3.3\% of the sampled farmers had 1 - 5 years of farming experience, 44.2\%; 11 - 15years and 37.5\% had 15 years and above. This implies that majority of the farmers studied were experienced in farming, hence could know when best to embark upon off farm generating income, particularly those that are engaged at the same period with farming activities without posing threat to his/her farm production and productivity (Ume et al. 2018).

The table 3 shows that high proportion (35.83\%) of the respondents engage in civil service. The interviewed respondents reported that engaging in civil service gives them the time they need to cultivate in their farms. The result is in line with the findings of Ruben et al. (2001), who reported that most civil servants always have additional stream of income as their salaries in most developing countries are meager for family upkeep

Unskilled wage work contributed over $14 \%$ of the total of off-farm work engaged by the respondents. Unskilled work is workforce that characterized of limitedskill and low educational status, hence are often engage in off farm income generations activities that are frequently tedious, low wage earning and risky in nature (Ahituv and Kimhi 2002). Furthermore, 10.83\% of the respondents engaged in either trading in agricultural or industrial finished goods under a roof, stores or hawking those (Ruben et al. 2001). However, other sources of off farm employment engaged by the respondents were motor driving, automobile mechanics and bike riders

Table 1 Description of Variables used in Logistic regression Model

\begin{tabular}{llc}
\hline Variable & Measurement & A priori expectation \\
\hline Age & Age of the household head in years. & - \\
Educational Level & Years of schooling in years. & + \\
Extension Services & No . of times of extension agent visits & - \\
Access to credit & Access to money to be used in the farm gotten from formal or & + \\
& informal sector. & + \\
Household Size & No .of people that resides and fed by the household head & + \\
Membership of Organization & Membership of organ.; 1 ; otherwise, 0 & + \\
Gender & Male, 1 and females; 2 & + \\
Farm Size & No of hectares of land cultivated by the farmer & + \\
Farming experience & Years of farming by the farmer & \\
\hline
\end{tabular}

The table shows that $55.8 \%$ of the females participated in off-farm income activities, while $44.2 \%$ participants were males. 
As well, the majority of the respondents (60.83\%) had farm size of the range 2-4 plots of land, whereas below two plots was the least. This implies that access to land could be a factor to participate in off-farm activities, in order to procure finances in expanding the farming scope, payment of hired labourers and purchasing of production inputs (Ume et al. 2017). Also, Access to extension services increased farmers' knowledge about best practices hence increases their productivity. The table 1 shows that half of the respondents have access to extension service delivery. More so, majority of the respondents (65.83\%) do not belong to any cooperative society, while $34.17 \%$ belonged to one form of cooperative society or the other. Cooperative helps members in gaining access to opportunities in diversifying their income generating activities outside farm income through among others cross fertilizations of information and ideas (Yue and Sonado 2013). Access to credit through formal and informal credit facilities were accounted by $37.17 \%$ of the respondents, while $65.83 \%$ do not have access. This means that most respondents have poor access to credit, implying that they might have high desire to embark upon off farm income to abate their income restraints in achieving their production goal (Mishra and Sandretto2001).

The coefficient of gender was found to significant and had indirect relationship to off farm income against apriori expectation. The negative sign of the coefficient could be to the fact that women in Muslim communities are in puda, hence are not allowed to partake in off farm income activities However, Babatunde et al. (2010) and Ume et al. (2017) established positive relation between gender and participation in off farm income activities. They opined that women in south east, Nigeria engage in lots of income earning activities such as trading, processing, saloon, and pottery to supplement household head income. The coefficient of age of household was positive in line with Ume et al. (2018), who attributed that to experience gained over many years of experimentations in various off farm activities. However, Ahituv and Kimhi (2002) reported a negative relationship between the two variables. The sign identity they correlated to the fact that with rising in experience, the greater the growing employment opportunities, but at declining age, such opportunities might start fading out (Beyene 2008). The coefficient of household size was positive and significant at $1 \%$ level of probability. This implies that farmers with higher household size had the more need to participate in off-farm activities in order to meet with responsibility of taking care of their welfare. In addition, farming household with large size especially those of labour age could be engaged in off farm income activities in order to generate income to be used to argument household head income in meeting their domestic and farm needs (Godwin and Bruer 2003). 
Sustainability, Agri, Food and Environmental Research, (ISSN: 0719-3726), 8(2): 155-170 http://dx.doi.org/10.7770/safer-V0NO-art1957

Table 2: Distribution of the Respondents According to Socio-economic Characteristics of the Farmers

\begin{tabular}{|c|c|c|}
\hline Variable & Frequency & Percentage \\
\hline \multicolumn{3}{|l|}{ Gender } \\
\hline Male & 53 & 44.2 \\
\hline Female & 67 & 55.8 \\
\hline \multicolumn{3}{|l|}{ Age } \\
\hline$<20$ & 3 & 2.5 \\
\hline $20-30$ & 29 & 24.2 \\
\hline $31-40$ & 37 & 30.8 \\
\hline$>40$ & 51 & 42.5 \\
\hline \multicolumn{3}{|l|}{ Marital Status } \\
\hline Single & 17 & 14.2 \\
\hline Married & 82 & 68.3 \\
\hline Widowed & 21 & 17.5 \\
\hline \multicolumn{3}{|l|}{ Household Size } \\
\hline $1-3$ & 16 & 13.3 \\
\hline $4-6$ & 38 & 31.7 \\
\hline $7-10$ & 39 & 32.5 \\
\hline$>11$ & 27 & 22.5 \\
\hline \multicolumn{3}{|l|}{ Educational Level } \\
\hline No Formal Education & 22 & 18.3 \\
\hline $1-6$ & 33 & 27.5 \\
\hline $7-12$ & 36 & 30 \\
\hline $13-17$ & 29 & 24.2 \\
\hline \multicolumn{3}{|l|}{ Farming Experience } \\
\hline $1-5$ & 4 & 3.3 \\
\hline $6-10$ & 18 & 15 \\
\hline $11-15$ & 53 & 44.2 \\
\hline$>15$ & 45 & 37.5 \\
\hline \multicolumn{3}{|l|}{ Farm Size (Plots) } \\
\hline$<2$ & 8 & 6.7 \\
\hline $2-4$ & 73 & 60.83 \\
\hline 5 and above & 39 & 32.50 \\
\hline \multicolumn{3}{|l|}{ Extension Services } \\
\hline Access & 60 & 50 \\
\hline No Access & 60 & 50 \\
\hline \multicolumn{3}{|l|}{ Cooperative } \\
\hline Member & 41 & 34.17 \\
\hline Non member & 79 & 65.83 \\
\hline \multicolumn{3}{|l|}{ Access to credit } \\
\hline Yes & 79 & 65.83 \\
\hline No & 41 & 34.17 \\
\hline
\end{tabular}


Sustainability, Agri, Food and Environmental Research, (ISSN: 0719-3726), 8(2): 155-170 http://dx.doi.org/10.7770/safer-V0NO-art1957

Table 3: Distribution of Respondents According to the Off-Farm Activities engaged in. multiple Responses

\begin{tabular}{|c|c|c|c|}
\hline Off farm Activities & Sub activities & Frequency & Percentage \\
\hline \multicolumn{4}{|c|}{ Unskilled wage works } \\
\hline Civil Service & & 17 & 14.17 \\
\hline Trading & & 43 & 35.83 \\
\hline \multirow[t]{4}{*}{ Driving } & & 13 & 10.83 \\
\hline & Okada riding & 3 & 2.31 \\
\hline & Tricycle riders & 6 & 4.23 \\
\hline & Bus drivers & 2 & 1.99 \\
\hline \multicolumn{4}{|l|}{ Weaving } \\
\hline \multicolumn{4}{|l|}{ Palm wine tapping } \\
\hline \multicolumn{4}{|l|}{ Craft making } \\
\hline & Wood & 0 & 0 \\
\hline & Calabash & & \\
\hline & Carpentry & 1 & 0.88 \\
\hline & $\begin{array}{l}\text { Leather work and } \\
\text { weaving }\end{array}$ & 0 & 0 \\
\hline & Pot making & 0 & 0 \\
\hline & Hair Saloon & 5 & 4.33 \\
\hline \multicolumn{4}{|l|}{ Mechanics } \\
\hline & Bicycle repairers & 0 & 0 \\
\hline & Vulcanizer & 0 & 0 \\
\hline & Tricycle repairer & 1 & 0.88 \\
\hline & $\begin{array}{l}\text { Motor } \quad \text { cycle } \\
\text { repairer }\end{array}$ & 0 & 0 \\
\hline & Car repairer & 3 & 3.33 \\
\hline & Electronics & 0 & 0 \\
\hline & repairer & & \\
\hline
\end{tabular}

Source: Field Survey (2018) 
Sustainability, Agri, Food and Environmental Research, (ISSN: 0719-3726), 8(2): 155-170 http://dx.doi.org/10.7770/safer-V0NO-art1957

Table 4: Logistic Result on the Determinants of Participation in Off-Farm Activities

\begin{tabular}{lcc}
\hline Tested variables & Coefficient & Z-value \\
\hline Constant & -6.350 & $-2.300^{* *}$ \\
Gender & 0.266 & 2.470 \\
Age (years) & -0.207 & -0.010 \\
Marital status & -0.003 & $3.570^{* *}$ \\
Household size & 1.160 & $1.810^{*}$ \\
Educational qualification & 0.750 & 0.180 \\
Farming experience & 1.365 & $-2.500^{* *}$ \\
Farm size & 3.259 & $3.750^{* *}$ \\
Membership of cooperative & -2.385 & $-1.41^{*}$ \\
Access to credit & 0.973 & -1.470 \\
Access to irrigation facilities & -0.324 & \\
\hline
\end{tabular}

Psudo $R^{2}=0.6018$ Prob $>$ Chi $=0.0000$ LR Chi $(10)=75.48$, Log likelihood $=-24.977392$

$* * *, * *$ and $*$ shows significant at $1 \%, 5 \%$ and $10 \%$ level of probability respectively.

In the same way coefficient of educational level was positive and significant at $10 \%$ level of probability. This shows that the educated farmers participate in non-farm activities than less or none educated, since the educated have skills, technical knowhow and ease of access to information, which may possibly compel their participation in high-paying nonagricultural wage employment which correlates directly with healthier household livelihood in form of expenditure on virtually all indispensable goods and services (Raman 2007). The aforementioned scenario concurred to a positive consequence of high-return nonfarm employment on family welfare. Educated individuals are more innovative and entrepreneurial, therefore, have more chances of generating income from both farming and nonfarm activities respectively (Ncnamara and Wesa2005). The coefficient of farm size was negative, implying that households with large farm size have less empathy for nonfarm activities no matter the wage payment, compare to those households with small farm holdings. The coefficient of access 
to credit had negative relation with the participation in off farm income, which is in consent with the a priori expectation and finding of Ume et al. (2018). It is expected that farmers that had poor access to credit had a high propensity to engage in off-farm work, compare to those that have access. Araujo (2003) found a positive effect of credit access on participation in nonfarm employment in Mexico.

The coefficient of membership of organization had a positive identity with participation in off farm employment. The benefits associated with participation in groups may the reason for the direct relationship, including apart from greater access to production and market-related information and build trust and social cohesion and allows group members to gain bargaining power, is the ability to form and maintain reciprocal relationships that enable members to smooth shocks to household income through sharing sources of participation in off farm income that has high wage payments that poses very low risk (Reardon and Patrick Webb 2001)

Table 5: Constraints to Participation in Off-Farm Activities.

\begin{tabular}{lcc}
\hline Constraints & Mean & Decision \\
\hline Poor access to credit facility & 2.05 & Accepted \\
Ill health of farmers & 2.2 & Accepted \\
Old Age & 2.5 & Accepted \\
High level of Illiteracy & 2.5 & Accepted \\
Poor extension services & 2.0 & Accepted \\
Seasonality of agricultural product & 1.3 & Rejected \\
Shortage of farm land & 1.2 & Rejected \\
Unavailability of off-farm work & 2.6 & Accepted \\
Fluctuations of market price & 1.3 & Rejected \\
Inadequate power supply & 1.7 & Accepted \\
Poor communication network & 1.4 & Rejected \\
\hline
\end{tabular}

Source: Field Survey, 2018.

Lack of access to credit was reported as constraint to farmers engaging in off farm income as shown in Table 2 by having a mean of 2.05, above the benchmark 1.5. Also, poor access to credit by farmer to undertake the procurement of essential farm inputs for high production and productivity may perhaps prompt his/her engagement in off farm income for a succor. The unwillingness of financial institutions to grant loans to the farmers, smallholder one in particular and high interest rate of the loans as charged by lending agencies may be the reasons for the poor access to credit (Ahituv and Kimhi 2002). In addition, poor access to formal educational was a challenge facing farmers in engaging in off farm activities. According to Barrett et al. (2001), education status of the farmer enhances his/her prospects of diversifying of income sources through embarking upon profitable off farm income activities 
and the skills to make such businesses very viable in order to keep afloat financially in undertaking farm and domestic matters. As well, age of the farmers is one of the major constraints to participating in off farm activities. This confirmed the findings of Barrett et al. (2001), who reported that farmers who are advanced in age are not usually willing to take up off farm activities, especially those that are labourous, tiresome and energy sapping to avoid risking their health. Conversely, the youthful farmers could be engaged in multiple off farm income activities in order to ensure multiple streams of income to improve their welfare.

In addition, ill health of the farmer was complained as limiting factor to farmers involving in off farm income activities. A sick person is often frail and may perhaps almost not carry out tasks that are energy sapping, tiresome and long hours of work (Aheamet al. 2006). Furthermore, poor inadequate power supply as seen in most rural and urban areas is major hindrance in any individual, farmers inclusive in opting for business in the related area. In most rural areas of most countries in sub- Saharan Africa, there is nonexistent of electricity and where there is existent, the power is very epileptic and not reliable power source for any business (Ume et al. 2018). Moreover, poor access to extension services is limiting factor to farmers' entrée to off farm income activities. This could be to the fact that extension services could be an avenue of informing farmers' sources of high paying off farm employment jobs (Araujo 2003).

As conclusion and recommendations, based on the findings, most of the farmers that participated in off-farm income activities were male, married, aged and educated. In addition, most of the respondents engaged in civil service and unskilled wage such as carpentry, car repairer and tricycle repairer. In addition, household size, education level, farming experience, farm size and membership of cooperative societies were the major determinants of participation in off-farm activities among the farmers in the study area. As well, poor credit facilities, poor extension services, seasonality of agricultural product, Shortage of farm land, failure in input or credit market, high cost of labour,poor communication network and Inadequate power supply were the farmers limiting factors in participation in off-farm activities.

Based on the research findings, the following recommendations were made, 1) Farmers should be encouraged to take up off farm activities to argument their income, which will improve their production output and raise their standard of living. 2) There is need to ensure farmers' credit faculty schemes to farmers through commercial banks and microfinance bank by government agencies concerned in order to encourage farmers to establish their off-farm businesses. 3) Farmers should be encouraged to engage in other off farm activities, such as skilled works and properly informed on its importance in uplifting farmers livelihood. 4) Farmers should be encouraged to belong or form cooperative societies in order to pull their resources together, as well to access government credits facility, in boosting their propensity of 
establishing off farm businesses to cushion the effects of financial limitation to their farming activities. 5) Some of the constraints highlighted such as health status can be improved on, through provision of well-equipped hospitals and clinics within the rural areas by government agencies concerned where the farmers can afford proper check-up bills. This may possibly energize the farmer to undertake off farm income activities to thrust their output frontier and smoothening their consumption. 6) Increase in farm size as one of the determinant factors for participation in off- farm income can be achieved through the government reviewing of the land decree Act of the nation. This will make it feasible for farmers to have access to farmland. 6) Our rural areas should be connected to greed through electrification to ensure farmers engaging in off farm income businesses that involved use of electricity, including wielding, electronic repairs and among others. 7) Extension services should be encouraged to sit up in their responsibilities by increasing the number of extension personnel in the job in order to bridge the ratio between the extension workers and the farmers and through payment of out of pockets expenses incurred in the course of discharging function

\section{REFERENCES}

Ahearn, M.C., El-Osta, H. and Dewbre, J. 2006. The impact of coupled and decoupled government subsidies on off-farm labor participation of U.S. farmoperators. American Journal of Agricultural Economics 88: 393-408.

Ahituv, A. and Kimhi, A. 2002. Off-farmwork and capital accumulationdecisions of farmersoverthelife-cycle: The role of heterogeneity and statedependence. Journal of DevelopmentEconomics 68: 329-353.

Araujo, C. 2003 Participation in off-farm employment in rural Mexico: The role of individual attributes, the local context, and social networks. Berkeley: University of California.

Babatunde, R., Olagunju, F., Fakayode, S., and Adejobi, A. 2010. Determinants of articipation in off-farm employment among small-holder farminghouseholds in Kwara state, Nigeria. Production Agricultural and technology,6: 1-14.

Barett, C. B., Reardon, T, and Webb, p. 2001. Nonfarmincomediversification and Householdlivelihoodstrategies in rural Africa: Concepts, Dynamics and Policyimplications. Foodpolicy, 26: 315-331.

Benjamin, C. and Kimhi, A. 2006. Farmwork, off-farmwork, and hiredlabour: estimatinga discretechoicemodel of French farmcouples' labourdecisions. EuropeanReview of AgriculturalEconomics 33: 149-171.

Beyene, A. D. 2008. Determinants of off-farmparticipationdecision of farmHouseholds in Ethiopia. Agrekon 47: 140-161. 
Bjornsen, H.M. and Mishra, A.K. 2012. Off-farmemployment and farmingefficiencyin modernagriculture. A dynamic panel analysis. Selectedpaperforpresentation at theAgricultural and AppliedEconomicsAssociation'sjointannual meeting, Washington. $31 \mathrm{pp}$.

Carriker, G.L., Langemeier, M.R., Schroeder, T.C. and Featherstone, A.M. 1993.Propensity to consume farmfamilydisposableincomefromseparatesources. American Journal of AgriculturalEconomics 75: 739-744.

Ellis, F. and Freeman, HA. 2004. Rural livelihoods and povertyreductionstrategies in fourAfricancountries. J. of developmentalstudies 40: 1-30.

Godwin, B.K. and Bruer, S.M. 2003. Anempiricalanalysis of farmstructure. and offfarmworkdecisions. Paperpresented at AAEA annual meeting, Motreal,Canada

Haggblade, S., Hazell, P.B., Reardon, T. 2007. Transforming the Rural Off-farm Economy, Johns Hopkins University Press, Baltimore, MD.

Kwon, C., Orazom, P.F.and Otto, D.M. 2006. Off-farm labor supplyresponsesTopermanent and transitoryfarmincome. AgriculturalEconomics 34: 59-67

Lagerkvist, C., Larsen, K. and Olson, K. 2006. Off-farmincome and farm capital accumulation: a farm-level data analysis. Annual Meeting of the American AgriculturalEconomicsAssociation, California. 22pp.

McNamara, K.T. and Weiss, C. 2005. Farmhouseholdincome and on- and offfarmdiversification. Journal of Agricultural and AppliedEconomics 37: 37-48.

Mishra, A.K. and Holthausen, D.M. 2002. Effect of farmincome and off-farmwagesvariabilityon off- farmlaboursupply. Agricultural and ResourceEconomicsReview

31: 187-199.

Mishra, A.K and Sandretto, C.L. 2001. Stability of farmincome and the role of non-farmincome in U.S. agriculture. Review of AgriculturalEconomics24: 208-221.

NPC (National Population Commission). 2006.Statistical bulletin of Nigeria Population Census. Rahman,M.2007. Socio-economicdeterminants of offfarmactivityparticipationBangladesh.RussianJournal of Agricultural And SocioEconomicScience1: 13.

Reardon, T., Stamoulis, K., Balisacan, A., Cruz, M., Berdegue, J.and Banks, D.1998. Rural non-farmincome in developingcountries. Thestate of food And agricultura 1998 283-356.

Reardon, T and Patrick W. 2001. Non-farm income diversification and household livelihood strategies in rural Africa: Concepts, dynamics, and policy implication. Food Policy 26:315331. 
Reardon T. 1997. Using evidence of household income diversification to inform study of the rural nonfarm labor market in Africa. World Development 25: 735-748.

Ruben, R. and Van den-Berg, M. 2001. Nonfarm Employment and Poverty):Alleviation of Rural Farm Households in Honduras. World Development 29.

Ume, S I, Eluwa,A N G. O. Okoro, G O and Silo, B J. 2017. Adoption of improved Cassava crop production technology by Agricultural Development. Programme (ADP) contactfarmers in Anambra state, Nigeria: a Training and Visit (T\&V) System Approach. International journal of innovations in Agricultural Science 1: 72-82.

Ume, S I, Ezeano, CI and Anozie, R.O. 2018. Role of off-farm income in agricultural production and its environmental effect in South East, Nigeria (A Case Study of Commercial Motor Cycle Business). International Letters of Social and Humanistic Sciences Submitted: 2018-04-19 ISSN: 2300-2697, Vol. 84, pp 1-13 Revised: 2018-08-25

Yue, B.andSonoda, D. 2012. "The effect of off-farm work on farm technical Efficiency in China". Working paper, Nagoya University. Furi-cho, Chikusa-ku, Nagoya, Japan.

Received: 24 $4^{\text {th }}$ May 2019; Accepted: $19^{\text {th }}$ June 2019; First distribution: 23th December 2019; Final publication: 01th Jule 2020. 